\title{
EFFECT OF TAX AMNESTY POLICY, KNOWLEDGE OF TAXATION AND SERVICES OF TAX AUTHORITIES ON TAXPAYERS COMPLIANCE: EMPIRICAL STUDY ON SATURN SERVICE OFFICE PAJAK PRATAMA TAX YEAR 2012-2016
}

\author{
Meilivia M. G Suak ${ }^{1}$ \\ ${ }^{1}$ Accounting Profession Program, Economics and Business Faculty, Sam Ratulangi University, Jl. Kampus \\ Bahu, Manado, 95115, Indonesia \\ Corresponding e-mail: gloriasuak@gmail.com
}

\begin{abstract}
Tax has an important role in the source of state revenue, because the largest income of the State comes from the tax sector. The importance of tax compliance ( tax compliance) in increasing tax receipts and/or tax ratio has encouraged the conduct of research on the determinants or factors that affect compliance. tax is the policy of tax amnesty, knowledge of taxation, and service of tax authorities. This study aims to analyze the effect of tax amnesty policy, knowledge of taxation, and tax authorities services on taxpayer compliance, empirical studies at the Pratama Tax Office Manado Tax Year 2012-2016. The questionnaire was distributed to 42 respondents and in the process with multiple linear analysis methods with SPSS version 22. This study consisted of dependent variables and independent variables. The dependent variable is taxpayer compliance, while the independent variable is the tax amnesty policy, knowledge of taxation, and service of tax authorities. The results showed that the tax amnesty policy did not have a positive and insignificant effect on taxpayer compliance, tax knowledge did not have a positive and insignificant effect on taxpayer compliance, tax authorities' services had a positive and significant effect on taxpayer compliance.
\end{abstract}

Keywords : tax amnesty policy, tax knowledge, tax services, taxpayer compliance

JEL Classification : H24, H26, H29

Article info:

Received 1 July 2019

Revised 23 July 2019

Accepted 26 July 2019

Available online 31 July 2019

\section{INTRODUCTION}

The tax collected by government is useful for financing government administration and development. The government as the recipient of the tax always tries to increase the amount of tax received to meet the State Budget (APBN). Tax revenues from year to year always increase. Taxes provide a fairly high contribution to state revenues for five years from 2012-2016, which is a percentage of over 70\%, even reaching 85\% in 2015 and 2016. This reflects that taxes play a significant role in the APBN. The high tax revenue in a country should be balanced with the high tax ratio. The tax ratio is a comparison between the amount of tax revenue compared to gross domestic product (GDP) of a country. Simanjuntak and Mukhlis (2012) in Yudharista (2014: 2) state that tax ratio is one indicator used by the government to measure success in state revenues from tax. In fact, despite increasing tax revenues, Indonesia has a relatively low tax ratio, this indicates that the government has not succeeded in optimizing tax revenues. 
Pratama Manado Tax Office is a vertical institution under the DGT whose duty is to collect tax revenues with the working area of Manado City and Tomohon City. As with other KPPs, Manado Pratama KPP gets a mandate every year to reach the revenue target. In recent years, KPP Pratama Manado has not succeeded in achieving targeted tax revenues. The Tax Pratama Manado Pratama Tax Ratio is in the range of $6 \%$ lower than the national tax ratio which is around $11 \%$. The gap ( tax gap ) of 5\% is something that must be closed with hard work. More if you have to reach a tax ratio of 15-16\% as desired by President Joko Widodo. The tax gap also shows that there is potential for tax revenue from unexplored business actors. optimally.

\section{LITERATURE REVIEWS}

\subsection{Tax}

According to Mardiasmo (2011: 01), tax is a people's contribution to the state treasury based on the law (which can be forced) by not receiving reciprocal services (contraptions) which can be directly shown and used for the public interest.

\subsection{Taxpayer compliance}

Efforts to improve taxpayer compliance have been carried out by the Director General of Taxes, one of which is to implement a tax amnesty policy, self assessment system. The theory that explains these conditions is the attribution and theory of planned behavior theory that is explaining someone's motivation to comply with the obligation to pay taxes based on two factors, namely internal factors and external factors, besides that it also explains that someone's obedience is followed by attitudes, norms and characteristics possessed by individuals. Taxpayers are included in the category of compliant taxpayers based on Minister of Finance Regulation Number 74/PMK.03/2012 Article 2 concerning procedures for Determining Taxpayers with Specific Criteria, if they meet the criteria as follow: (a) timely in delivering Notification Letter; (b) has no tax arrears for all types of taxes, except tax arrears that have obtained permission to pay in installments or delay payment of taxes; (c) the financial statements are audited by a Public Accountant or government financial supervision institution with a reasonable opinion without exception for 3 (three) consecutive years; and (d) never been convicted of committing a criminal offense in the field of taxation based on a court decision that has had permanent legal force within the last 5 (five) years.

\subsection{Tax amnesty}

According to PMK No. 118/PMK.03/2016 tax amnesty is elimination of tax owed should not be sanctioned tax administration and criminal sanctions in the field of taxation, by way of uncovering treasure and pay the ransom money as stipulated in the Law on Tax Forgiveness. Indonesia can consider implementing a tax amnesty policy in various forms to improve tax compliance (Ngadiman and Huslin, 2015: 233).

\subsection{Taxation knowledge}

According to Carolina (2009) in Khasanah (2014: 22), knowledge of tax is tax information that can be used by taxpayers as a basis for acting, making decisions, and for taking certain directions or strategies in connection with the implementation of rights and obligations in the field of taxation. Theory of Planned Behavior (TPB) explains that the behavior generated by individuals arises because of the intention to behave, it is related to the awareness of taxpayers. According to Suryadi (2006), awareness of taxpayers will increase if the public has a positive perception of taxes. By increasing the knowledge of taxation in society through knowledge of taxation, both formal and informal will have a positive impact on the awareness of taxpayers to pay taxes.

\subsection{Ministry of fiscal}

Jatmiko (2006) in Arum (2012: 19) states that, service is a way of serving (helping to care for or preparing for all the needs needed by a person). Meanwhile, tax authorities are tax 
officers which makes service tax authorities can be interpreted as a way of tax officers in helping, managing, or preparing all needs of everyone who in this case is a taxpayer.

\section{RESEARCH METHOD}

\subsection{Data}

The type of research used to analyze tax amnesty policy, knowledge of taxation, and service of tax authorities influences taxpayer compliance, the 2012-2016 of tax year in the Pratama Manado Tax Office is a quantitative method. According to Sugiyono (2011) the quantitative research method is a research method based on the philosophy of positivism, used to examine certain populations or samples of data collection using research instruments, statistical data analysis with the aim of testing the hypothesis set.

\subsection{Sample}

Sampling used in this study is non probability sampling with sampling techniques using incidental sampling where the determination of the sample is based on spontaneity factors that is anyone in this case the taxpayer accidentally or accidentally met with the researcher and according to their characteristics, then the person can be used as a sample (Sugiyono, 2011: 67). This study uses Slovin formula with an error rate of 10\% and get 100 respondents as sample.

\subsection{Method of analysis}

According to Sugiyono (2011: 97), the research instrument is a tool used to measure observed natural and social phenomena. The instrument in this study was a questionnaire before being used as an instrument in this study before testing was carried out through validity and reliability. The analysis technique in this study was descriptive statistical analysis and inferential statistical analysis.

\section{RESULTS AND DISCUSSIONS}

\subsection{Result}

Hypothesis testing in this study was carried out by simple linear regression analysis and multiple linear analysis. Simple linear analysis is used to test the first hypothesis, and secondly to find out the effect of the tax amnesty policy on individual taxpayer compliance. The multiple linear regression test was used to test the third hypothesis, namely the influence of tax amnesty policy, taxation knowledge, and fiscal services on taxpayer compliance. Multiple linear regression analysis is used to solve the existing problem formulation, namely to see the influence between two or more variables. Table 1 presents the results of multiple linear regression analysis.

\section{Table 1. Results of multiple linear regression}

\begin{tabular}{lr}
\hline Independent variables & Coefficient \\
\hline Constant & 3,370 \\
Forgiveness & $-0,117$ \\
Knowledge & 0,058 \\
Service & $0,698^{* * * *}$ \\
F test & $63,735^{* * *}$ \\
R & 0,913 \\
R Square & 0,834 \\
\hline Dependent variable is compliance. $* * *$ indicates statistical significance at 0.05 &
\end{tabular}

Based on the results in the table above the multiple regression equation is obtained as follows:

$$
\mathrm{Y}=\mathbf{3 , 3 7 0}+(-0,117 \mathrm{X} 1)+\mathbf{0 , 0 5 8 X 2}+\mathbf{0 , 6 9 8 X 3}+\mathrm{e}
$$

From this equation can be explained as follow: 
Constant. In the equation above the constant value is 3,370, which means that if it is not influenced by the independent variables, namely the tax amnesty policy, tax knowledge, and tax office services, taxpayer compliance is 3,370 .

Tax amnesty policy $\left(X_{1}\right)$. For the tax amnesty policy variable, the coefficient value of -0.117 is obtained, which means that if the tax amnesty policy variable increases one unit, then taxpayer compliance will increase by -0.117 units. Assuming other independent variables are fixed. The regression coefficient which is negative 0.165 also shows that the tax amnesty policy has a negative effect on taxpayer compliance.

Tax knowledge $\left(X_{2}\right)$. For the tax knowledge variable, the coefficient value of 0.058 is obtained, which means that if the tax sanction variable increases one unit, then tax compliance will increase by 0.058 units. Assuming other independent variables are fixed. The regression coefficient value of negative 0.563 also shows that tax knowledge has no effect on taxpayer compliance.

Service quality of the fiscal $\left(X_{3}\right)$. For the tax authorities service quality variable, a coefficient value of 0.698 is obtained which means that if the tax authorities service quality variable increases by one unit, then taxpayer compliance will increase by 0.698 units. Assuming that the other independent variables are fixed. The value of the regression coefficient which is positive 0,000 also shows that the service quality of the tax has a positive effect on taxpayer compliance.

\subsection{Discussion}

This test is conducted to determine whether the independent variable used is feasible or not as an explanatory variable or predictor. $\mathrm{H} 1$ in this study was rejected, that is, the Tax Amnesty Policy had a negative effect on tax compliance in the Pratama Tax Office Manado. Where the regression results indicate that the Tax Amnesty Policy variable has a value that is not significant above 0.05 , which is equal to 0.165 . The Tax Amnesty policy is one of the policies in the field of taxation carried out by the Director General of Taxes. The Tax Amnesty policy is also needed to increase knowledge of taxpayer compliance following the tax amnesty policy. However, due to the knowledge of the amnesty is still low Tax Policy possessed the taxpayer, then the lower the taxpayer's awareness so as to reduce tax compliance in meeting tax obligations. Conversely, if there is more knowledge about the tax amnesty policy known to taxpayers, the higher the awareness of the taxpayer so that it can improve taxpayer compliance in fulfilling its tax obligations.

$\mathrm{H} 2$ in this study was rejected, that is, knowledge of taxation had a negative effect on tax compliance in the Pratama Tax Office Manado. Where the regression results indicate that the tax authorities service variable has a significance value above 0,05 which is equal to 0.563. Knowledge level of taxpayers at KPP Pratama Manado is still low. Knowledge is very important in helping taxpayers in carrying out their obligations. A taxpayer must first know what is his obligation. The more knowledge of taxation known by taxpayers, the higher the awareness of taxpayers so that they can increase taxpayer compliance in fulfilling their tax obligations, conversely if the less tax knowledge is obtained by taxpayers, the lower the level of taxpayer compliance in fulfilling their tax obligations.

H3 in this study was accepted, that is, Fiscal Services had a positive effect on tax compliance in the Pratama Tax Office Manado. Where the regression results indicate that the tax authorities service variable has a significance value below 0,05 which is equal to 0,000 . This proves that the better the quality of tax services provided to taxpayers, the taxpayer compliance in KPP Manado also increases, because the quality of service quality of tax authorities increases greatly facilitates taxpayers to fulfill their tax obligations, such as DJPonline services. Where all payments, tax reporting can be done from anywhere without having to queue. 


\section{CONCLUSION}

Based on the results of this study then it can be concluded that: (a) the tax amnesty policy does not have a positive and insignificant effect on Taxpayer Compliance at the Pratama Tax Office in Manado. This can be seen from the magnitude of the regression coefficient which is negative which is 0.165 greater than 0.05 . Based on these values indicate that the tax amnesty does not affect the taxpayer compliance at Manado KPP Pratama; (b) tax knowledge does not have a positive and insignificant effect on Taxpayer Compliance at the Manado Pratama Tax Office. This can be seen from the magnitude of the regression coefficient which is negative which is 0.563 greater than 0.05 . Based on these values indicate that knowledge of taxation does not affect Taxpayer Compliance at KPP Pratama Manado; and (c) fiscal Services have a positive and significant effect on Taxpayer Compliance at the Pratama Tax Office in Manado. This can be seen from the magnitude of the regression coefficient value which is negative which is 0,000 smaller than 0.05 . Based on this value, it shows that the tax authorities' service has an effect on Taxpayer Compliance at Manado Tax Office.

Based on those conclusions then this study suggests that: (a) for the Tax Service Office (KPP) Pratama Manado better to conduct socialization of tax counseling more frequently so that it will raise public awareness of tax compliance. There is still a lack of socialization of counseling to taxpayers, resulting in a lack of public responsibility for taxes. The Tax amnesty policy has proven to have no effect on tax compliance because there are still many taxpayers who do not understand the tax amnesty policy. If the tax extension improved the dissemination of knowledge of the taxpayer's rights and their responsibilities in taxation will increase; (b) for further studies in the same area, it is recommended to add tax extension variables as a process of educating taxpayers and taking respondents who are directly involved in the Tax amnesty Policy program to get answers directly from people involved in the program; (c) the researchers also suggested for further research to expand the object of research; and (d) the number of samples used is relatively small, so it is expected that further researchers can use more samples.

\section{REFERENCES}

Arum, H. P 2012. Effects of Taxpayer Awareness, Tax Services, and Tax Sanctions on Taxpayer Compliance of Individuals Conducting Business Activities and Free Work (Study in the Primary Tax Office of Cilacap). Thesis. Diponegoro University. Now.

Decision of Chairman of Bapepam LK No: KEP-431 /BL/2012 concerning Submission of Annual Report of Issuers or Public Companies.

Tax Forum. 2016. Tax Amnesty Facility . http://forumpajak.org/fasilitas-pengampunanpajak-taxamnesty/ . October 2, 2016 (11:58)

Khasanah, SN 2014. Effect of Tax Knowledge, Modernization of Tax Administration System, and Taxpayer Awareness on Taxpayer Compliance in 2013 Regional Office of the Directorate General of Taxes in Yogyakarta. Thesis . Yogyakarta State University. Yogyakarta.

Ministry of Finance of the Republic of Indonesia. 2016. Financial Note and Income and Expenditure Budget Design for Fiscal Year 2016. http://www.anggaran.depkeu.go.id/Content/Publikasi/NK\%20APBN/NK\%20APBN $\% 2020$ 16.pdf . September 15, 2018 (15:36)

Ministry of Finance of the Republic of Indonesia.2016. Information on the 2016 State Budget. Http://www.kemenkeu.go.id/sites/default/files/bibfinal.pdf September 15, $2018(15: 36)$ 
Mardiasmo. 2011. Perpajakan 2011 Revised Edition . ANDI. Yogyakarta

Ngadiman, and D. Huslin. 2015. Effects of Sunset Policy, Tax Amnesty, and Tax Sanctions on Taxpayer Compliance (Empirical Study at Pratama Jakarta Tax Office Kembangan). Journal of Accounting, 12 (2): 225-241.

Regulation of the Minister of Finance of the Republic of Indonesia Number 118 / PMK. 03/2016 concerning the Implementation of Law No. 11 of 2016 concerning Tax Amnesty. 15 July 2016. News of the Republic of Indonesia. Jakarta

Regulation of the Minister of Finance of the Republic of Indonesia Number 74 / PMK.03 / 2012 concerning Procedures for Determination and Revocation of Determination of Taxpayers with Certain Criteria in Pramushinta, and B. Siregar.2011. Effects of Tax Services and Sunset Policy Implementation on Taxpayer Compliance in Efforts to Increase Taxes. Journal of Economics and Business , 5 (2): 173-189.

Sugiyono. 2011. Business Research Methods . Alfabeta. Bandung.

Suryadi. (2006). Model hubungan kausal kesadaran, pelayanan, kepatuhan wajib pajak dan pengaruhnya terhadap kinerja penerimaan pajak: Suatu survei di wilayah Jawa Timur. Jurnal Keuangan Publik, 4(1), 105-121

Yudharista, K. (2014). Pengaruh kesadaran wajib pajak, pelayanan fiskus, sanksi pajak, pengetahuan dan pemahaman perpajakan terhadap kepatuhan wajib pajak orang pribadi yang melakukan kegiatan usaha dan pekerjaan bebas (Studi di wilayah KPP Pratama Tulungagung). Skripsi. Universitas Airlangga, Surabaya. 